\title{
Current insights into renal ciliopathies: what can genetics teach us?
}

\author{
Heleen H. Arts • Nine V. A. M. Knoers
}

Received: 10 April 2012 /Revised: 20 June 2012 / Accepted: 21 June 2012 /Published online: 25 July 2012

(C) The Author(s) 2012. This article is published with open access at Springerlink.com

\begin{abstract}
Ciliopathies are a group of clinically and genetically overlapping disorders whose etiologies lie in defective cilia. These are antenna-like organelles on the apical surface of numerous cell types in a variety of tissues and organs, the kidney included. Cilia play essential roles during development and tissue homeostasis, and their dysfunction in the kidney has been associated with renal cyst formation and renal failure. Recently, the term "renal ciliopathies" was coined for those human genetic disorders that are characterized by nephronophthisis, cystic kidneys or renal cystic dysplasia. This review focuses on renal ciliopathies from a human genetics perspective. We survey the newest insights with respect to gene identification and genotype-phenotype correlations, and we reflect on candidate ciliopathies. The opportunities and challenges of next-generation sequencing (NGS) for genetic renal research and clinical DNA diagnostics are also reviewed, and we discuss the contribution of NGS to the development of personalized therapy for patients with renal ciliopathies.
\end{abstract}

Keywords Cilia $\cdot$ Renal ciliopathies $\cdot$ Renal cysts · Genotype-phenotype correlations $\cdot$ Next-generation sequencing $\cdot$ Personalized medicine

\footnotetext{
H. H. Arts $(\bowtie)$

Department of Human Genetics, 6525 GA Nijmegen, The Netherlands

e-mail: h.arts@gen.umcn.nl

N. V. A. M. Knoers

Department of Medical Genetics, University Medical Center Utrecht, 3508 AB Utrecht, The Netherlands
}

Nijmegen Centre for Molecular Life Sciences, and Institute for Genetic and Metabolic Disease, Radboud University Nijmegen Medical Centre,

\section{Introduction}

Cilia

Cilia are membrane-enclosed hair-like cell organelles that occur on the apical surface of renal tubular cells and on cells in many other organs. Cilia are conserved among species and were first described by the Dutch scientist Antoni van Leeuwenhoek, the father of microscopy and cell biology, who reported ciliated micro-organisms that used their cilia as "little legs" for movement $[1,2]$. It appears that many cell types in the human body, such as sperm cells and the respiratory epithelial cells, also contain motile cilia. The cilium, or flagellum, of a sperm cell allows the cell to move, whereas cilia in the respiratory system propel mucous over the cell surface [3]. In this review, we will focus on the immotile brother of the motile cilium, the so-called primary cilium, which appears and functions as a cell antenna of renal cells and cells throughout the human body (Fig. 1) [3, 4]. Structurally, the primary cilium is composed of a basal body from which the cilium initially assembles, a transition zone that is important for anchoring the cilium to the membrane and regulating protein traffic in and out of the cilium, and the ciliary axoneme, which contains a ring of microtubule bundles connecting the ciliary base with the tip. The microtubules form the skeleton of the cilium and are literally a "highway" for ciliary transport (intraflagellar transport, or IFT), a process that was first observed in the unicellular green alga Chlamydomonas reinhardtii and that has recently been extensively reviewed by Ishikawa and Marshall $[5,6]$. This transport process is bidirectional, base-to-tip (anterograde) and tip-to-base (retrograde), and occurs through interactions of the kinesin- 2 motor in association with the IFT complex B proteins or the cytoplasmic dynein motor 2 linked to IFT complex A proteins respectively [5]. IFT allows movement of cargo through the cilium and is important for ciliogenesis and for signaling cascades that regulate development and tissue homeostasis [3, 4]. 


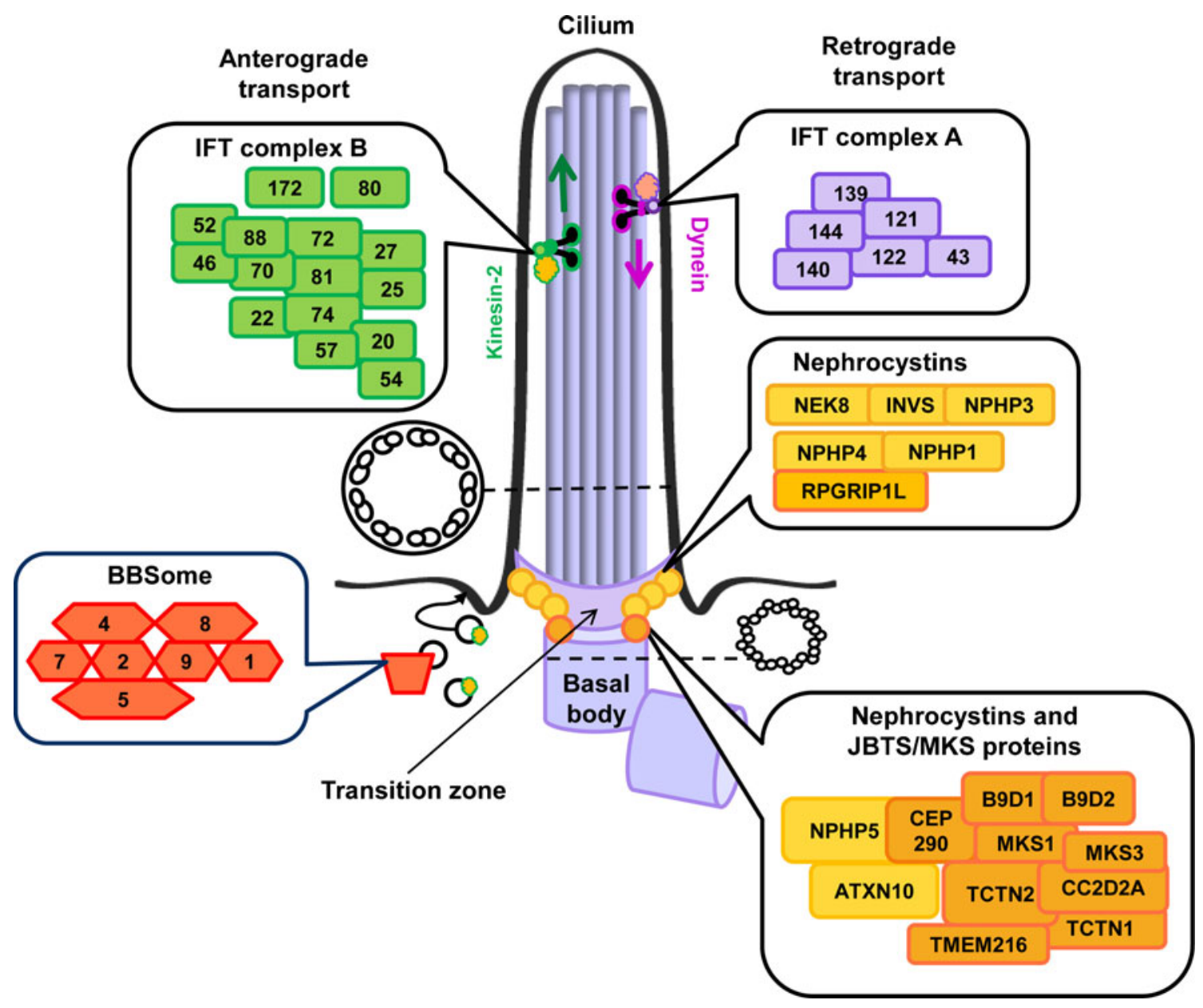

Fig. 1 The primary cilium and ciliary protein complexes. The primary cilium is a membrane-enclosed antenna-like structure with a ringshaped skeleton that consists of 9 doublets of microtubules. The ciliary base is called the "basal body", and consists of triplets of microtubules. Ciliary transport, intraflagellar transport (IFT), occurs from base-to-tip mediated by the IFT complex B (green) in association with a kinesin II motor and from tip-to-base by the IFT complex A (purple) in association with the cytoplasmic dynein motor 2 . Other protein complexes

\section{Ciliary dysfunction and renal insufficiency}

One of the first papers that linked ciliary disruption to the development of cystic kidneys in mammals was published by the group led by Douglas Cole in 2000 . In their paper they describe ciliary abnormalities and renal disease in a mouse model with a hypomorphic mutation in the Ift88 gene that encodes a protein that is part of the IFT B complex (Fig. 1) [7]. To date, we know that ciliary disruption is linked to a variety of human genetic kidney disorders, such as autosomal dominant and recessive polycystic kidney disease (ADPKD and ARPKD), tuberous sclerosis (TSC), medullary cystic kidney disease (MCKD), and nephronophthisis and related disorders $[3,4]$. Here, we will predominantly focus on the latter group of disorders. are the BBSome (red) consisting of various BBS proteins, and networks of nephrocystins (yellow), and Meckel-Gruber (MKS) and/or Joubert (JBTS) syndrome-associated proteins (orange). The BBSome is involved in trafficking membrane proteins to the cilium, while most nephrocystins and MKS/JBTS proteins localize to the transition zone where they are important for ciliogenesis, regulation of ciliary signaling and the docking and filtering of vesicles/proteins at the cilium

\section{Renal ciliopathies}

Nephronophthisis

Nephronophthisis literally means "damage to the nephrons." It is an autosomal recessive disorder that represents the most common monogenetic cause of renal insufficiency in children and young adults. It is enormously genetically heterogeneous, i.e., mutations in at least 13 different genes have been associated with nephronophthisis. In spite of that, $70 \%$ of patients still remain genetically unexplained [8]. In 1997, the first genetic cause of nephronophthisis was identified through the detection of a deletion that covered the NPHP1 gene $[8,9]$. Later, it became apparent that NPHPI is not only mutated in isolated nephronophthisis, but that a significant number of patients with NPHP1 mutations also display neurological 
symptoms. Some of these individuals have been reported to display cerebellar vermis hypoplasia and brainstem anomalies compatible with a Joubert syndrome diagnosis [10-12]. With respect to nephronophthisis, NPHPI is the most commonly mutated gene, as genetic defects in this gene explain the cause of disease in $20 \%$ of patients with this disorder [8], while all other nephronophthisis-associated genes (Table 1) have been found to be mutated with a much lower frequency. Remarkably, almost all of these genes encode proteins that interconnect in a dynamic "nephrocystin" protein complex that resides at the transition zone (Fig. 1) where it regulates ciliogenesis and protein sorting, thereby controlling renal development and homeostasis [13-15]. Yet, other localizations and functions of the nephrocystins are also known. Besides their ciliary roles, nephrocystins 1, 4, and RPGRIP1L (also known as nephrocystin-8) have been shown to regulate tight-junction formation at the cell junctions [16]. GLIS2 and nephrocystin-2 function in both the nucleus and the cilium [17, 18], and the recently identified XPNPEP3 biochemically processes several ciliary proteins and has been detected in mitochondria [19]. Clinically, it is difficult to diagnose nephronophthisis in early stages of the disease as children with this rare disorder initially present with nonspecific features such as polydipsia and polyuria [8]. As such, good medical care for patients with nephronophthisis (and other cystic kidney diseases) includes evaluation for other medical and developmental issues. Ultrasound, renal biopsies, and/or genetic tests are necessary to make a definite nephronophthisis diagnosis. Renal ultrasounds often show normal sized or small kidneys with increased echogenicity, and may reveal renal cysts, although cysts are not recorded in all nephronophthisis patients. Histologically, nephronophthisis is characterized by thickened and irregular tubular basement membranes, periglomerular and interstitial fibrosis, and (sporadic) cysts that often occur at the corticomedullary border (Fig. 2a) [8].

Syndromes associated with nephronophthisis

Nephronophthisis is often accompanied by anomalies in other organs (Table 2). This is not surprising given the fact that primary cilia occur almost ubiquitously throughout the human body [4]. Extrarenal features that are often observed include retinal degeneration, hepatobiliary disease, cerebellar vermis hypoplasia, laterality defects, intellectual disability and shortening of bones (ribs, phalanges and long bones) $[3,4]$. These features are represented in a variety of syndromes, including Senior-Løken syndrome (retinal degeneration causing blindness), Joubert syndrome (cerebellar vermis hypoplasia and brainstem abnormalities; the primary hallmark is the molar tooth sign in the brain), Bardet-Biedl syndrome (intellectual disability, obesity, and various other features), and Jeune asphyxiating thoracic dystrophy (shortening of the bones, the main characteristic is a narrow rib-cage) [3, 4]. In 2009, it was suggested by Baker and Beales and by Konstantinidou et al that Sensenbrenner syndrome, often but not always characterized by nephronophthisis, is also part of the ciliopathy spectrum based on the phenotypic overlap with the classic ciliopathies [20,21]. A year later the first genetic evidence was published by us and others supporting this assumption [22, 23]. We can therefore conclude that classification of classic and new ciliopathies allows ciliary gene prioritization facilitating gene hunting for these disorders. Sensenbrenner syndrome is characterized by several of the above-mentioned features, for instance, retinal degeneration, hepatobiliary disease, cerebellar vermis hypoplasia, and shortening of the bones in combination with craniosynostosis and ectodermal anomalies, such as skin laxity and tooth abnormalities [24-26]. To date, Sensenbrenner syndrome and the other ciliary disorders affecting skeleton development, such as Jeune syndrome, Ellis-van Creveld syndrome, Saldino-Mainzer syndrome, and the short-rib-polydactyly syndrome are referred to as "skeletal ciliopathies."

Renal cystic dysplasia and other renal phenotypes

Other renal phenotypes have also been associated with ciliary dysfunction. In severe syndromes that affect early human development, such as the Meckel-Gruber syndrome, which is characterized by neural tube defects and many other features, and the short-rib-polydactyly syndrome, fetuses present with cystic renal dysplasia, a congenital renal dysplasia in which the renal cortex is generally cystic, with distension of the terminal ends of the collecting ducts, and the medullary pyramids are poorly developed and demonstrate dysplastic structures and fibrous tissue (Fig. 2b) [3, 27-29]. Other renal phenotypes that have been described in ciliopathies are horseshoe kidneys [29, 30], lobulated kidneys [31], urinary tract infections and anomalies [32], and kidney stones [33]; however, the latter abnormalities are all much less commonly reported and it remains to be shown whether these features are (in part) the result of cilium dysfunction or not.

\section{Genetics of renal ciliopathies}

\section{Current genetic insights}

To date, mutations in roughly 50 genes have been associated with renal ciliopathies (Table 1). Although not all patients with mutations in these genes suffer from renal disease, we have to be aware of the fact that various genes were identified only recently in a few young patients in whom renal disease may still develop, and that a subset of genes have a low-mutation frequency. Improved insights into genotype- 
Table 1 Ciliary disease genes and renal phenotypes

\begin{tabular}{|c|c|c|c|c|}
\hline Symbol & Renal phenotype in patients & MIM Gene ID & Disorders & Reference (PMID) \\
\hline AHII & Nephronophthisis & 608894 & JBTS & 15322546 \\
\hline ALMS1 & Renal insufficiency & 606844 & ALSTR & $11941369 ; 11941370$ \\
\hline$A R L 13 B$ & No renal disease reported & 608922 & JBTS & 18674751 \\
\hline ARL6 & Renal failure, kidney stones & 608845 & BBS, RP & $\begin{array}{l}15258860 ; 15314642 ; \\
19858128 ; 19956407\end{array}$ \\
\hline ATXN10 & Nephronophthisis & 611150 & NPHP & 21565611 \\
\hline$B 9 D 1$ & Multicystic dysplastic kidneys & 614144 & MKS & 21493627 \\
\hline$B 9 D 2$ & Cystic kidneys & 611951 & MKS & 21763481 \\
\hline BBS1 & $\begin{array}{l}\text { Chronic renal failure, urinary tract infections and } \\
\text { anomalies }\end{array}$ & 209901 & BBS & 12118255 \\
\hline BBS10 & Meckel-like cystic kidneys & 610148 & BBS & 16582908 \\
\hline BBS12 & Renal disease reported & 610683 & BBS & 17160889 \\
\hline$B B S 2$ & $\begin{array}{l}\text { Meckel-like cystic kidneys, cystic kidneys, renal } \\
\text { hypoplasia }\end{array}$ & 606151 & BBS & 11285252 \\
\hline BBS4 & Meckel-like cystic kidneys, cystic kidneys & 600374 & BBS, LCA & 11381270 \\
\hline BBS5 & No renal disease reported & 603650 & BBS & 15137946 \\
\hline$B B S 7$ & Renal disease reported & 607590 & BBS & 12567324 \\
\hline BBS9 & Renal disease reported & 607968 & BBS & 16380913 \\
\hline$C C 2 D 2 A$ & Cystic dysplastic kidneys, nephronophthisis & 612013 & $\begin{array}{l}\text { COACH, JBTS, } \\
\text { MKS }\end{array}$ & $\begin{array}{l}\text { 19574260; 18387594; } \\
18513680 ; 18950740\end{array}$ \\
\hline CEP41 & Nephronophthisis (rare) & 610523 & JBTS & 22246503 \\
\hline CEP290 & Multicystic dysplastic kidneys, nephronophthisis & 610142 & $\begin{array}{l}\text { BBS, JBTS, MKS, } \\
\text { SLSN, LCA }\end{array}$ & $\begin{array}{l}\text { 17617513; 17564974; } \\
\text { 18327255; } \\
\text { 16682970; } 16682973 ; \\
16909394 ; 21068128\end{array}$ \\
\hline C5ORF42 & No renal disease reported & 614571 & JBTS & 22425360 \\
\hline $\mathrm{DYNC} 2 \mathrm{H1}$ & Cystic kidneys, Multicystic dysplastic kidneys & 603297 & ATD, SRP & 19442771 \\
\hline$E V C$ & No renal disease reported & 604831 & EVC & 10700184 \\
\hline$E V C 2$ & No renal disease reported & 607261 & EVC & 12468274 \\
\hline GLIS2 & Nephronophthisis & 608539 & NPHP & 17618285 \\
\hline HYLS1 & No renal disease reported & 610693 & HYLS & $15843405 ; 18648327$ \\
\hline IFT122 & Nephronophthisis & 606045 & CED & 20493458 \\
\hline IFT43 & Nephronophthisis & 614068 & CED & 21378380 \\
\hline IFT80 & No renal disease reported & 611177 & ATD, SRP & $17468754 ; 19648123$ \\
\hline IFT140 & Nephronophthisis & 614620 & ATD, SM & 22503633 \\
\hline INPP5E & No renal disease reported & 613037 & JBTS, MORM & $19668215 ; 19668216$ \\
\hline$I N V S$ & Enlarged (dysplastic) cystic kidneys & 243305 & NPHP, SLSN & $12872123 ; 16522655$ \\
\hline$I Q C B 1$ & Nephronophthisis & 609237 & SLSN, LCA & $15723066 ; 21220633$ \\
\hline KIF7 & No renal disease reported & 611254 & $\begin{array}{l}\text { ACRC, HYLS, } \\
\text { JBTS }\end{array}$ & $21633164 ; 21552264$ \\
\hline$M K K S$ & Meckel-like cystic kidneys, lobulated kidneys & 604896 & BBS, MKKS & $10973251 ; 10973238$ \\
\hline MKS1 & Renal cystic dysplasia & 609883 & MKS & 16415886 \\
\hline NEK1 & Cystic kidneys, horseshoe kidney (rare) & 604588 & SRP & 21211617 \\
\hline$N E K 8$ & Nephronophthisis & 609799 & NPHP & 18199800 \\
\hline NPHP1 & Nephronophthisis & 607100 & $\begin{array}{l}\text { NPHP, JBTS, } \\
\text { SLSN }\end{array}$ & $9326933 ; 15138899 ; 9856524$ \\
\hline NPHP3 & Nephronophthisis, renal cystic dysplasia & 608002 & $\begin{array}{l}\text { NPHP, MKS, } \\
\text { SLSN }\end{array}$ & $12872122 ; 18371931 ; 11752023$ \\
\hline NPHP4 & Nephronophthisis & 607215 & NPHP, SLSN & $12205563 ; 12244321$ \\
\hline OFD1 & Cystic kidneys & 300170 & JBTS, OFD, SGBS & $11179005 ; 19800048 ; 16783569$ \\
\hline OCRL1 & Renal proximal tubulopathy (Dent's disease) & 300535 & OCRL & 22228094 \\
\hline$P K D 1$ & Enlarged cystic kidneys & 601313 & ADPKD & 8004675 \\
\hline
\end{tabular}


Table 1 (continued)

\begin{tabular}{|c|c|c|c|c|}
\hline Symbol & Renal phenotype in patients & MIM Gene ID & Disorders & Reference (PMID) \\
\hline$P K D 2$ & Enlarged cystic kidneys & 173910 & ADPKD & 8650545 \\
\hline PKHD1 & Enlarged cystic kidneys & 606702 & ARPKD & $11898128 ; 11919560$ \\
\hline$R P G R I P I L$ & $\begin{array}{l}\text { Multicystic dysplastic kidneys, enlarged cystic } \\
\text { kidneys, nephronophthisis }\end{array}$ & 610937 & $\begin{array}{l}\text { COACH, JBTS, } \\
\text { MKS }\end{array}$ & $17558407 ; 17558409 ; 19574260$ \\
\hline$S D C C A G 8$ & Nephronophthisis & 613524 & SLSN, BBS & $20835237 ; 22190896$ \\
\hline TCTN1 & No renal disease reported & 609863 & JBTS & 21725307 \\
\hline TCTN2 & Enlarged cystic kidneys & 613846 & JBTS, MKS & $21565611 ; 21462283$ \\
\hline TMEM138 & Renal cystic dysplasia, nephronophthisis & 614459 & JBTS & 22282472 \\
\hline TMEM237 & Cystic kidneys & 614423 & JBTS & 22152675 \\
\hline TMEM216 & $\begin{array}{l}\text { Renal cystic dysplasia, cystic kidneys, } \\
\text { nephronophthisis }\end{array}$ & 613277 & JBTS, MKS & $20036350 ; 20512146$ \\
\hline TMEM67 & $\begin{array}{l}\text { Renal cystic dysplasia, (micro)cystic kidneys, neph- } \\
\text { ronophthisis }\end{array}$ & 609884 & $\begin{array}{l}\text { COACH, JBTS, } \\
\text { MKS, NPHP }\end{array}$ & $\begin{array}{l}19058225 ; 17160906 \\
16415887 \\
19508969\end{array}$ \\
\hline TRIM32 & No renal disease reported & 602290 & BBS & 16606853 \\
\hline TTC21B & Nephronophthisis & 612014 & ATD, NPHP & 21258341 \\
\hline TSC1 & Cystic kidneys, renal cancer & 605284 & $\mathrm{TSC}$ & 9242607 \\
\hline TSC2 & Cystic kidneys, renal cancer & 191092 & $\mathrm{TSC}$ & 7581393 \\
\hline TTC8 & Renal dysplasia (rare) & 608132 & BBS, RP & $14520415 ; 20451172$ \\
\hline$U M O D$ & $\begin{array}{l}\text { Renal (glomerulo)cystic disease, interstitial ne- } \\
\text { phropathy }\end{array}$ & 191845 & $\begin{array}{l}\text { MCKD, FJHN, } \\
\text { GCKD }\end{array}$ & $14570709 ; 12629136 ; 12471200$ \\
\hline$V H L$ & Renal cell carcinoma, cystic kidneys & 608537 & VHL & $2894613 ; 15611513$ \\
\hline$W D P C P$ & No renal disease reported & 613580 & BBS & 20671153 \\
\hline WDR19 & Nephronophthisis & 608151 & ATD, CED, NPHP & 22019273 \\
\hline WDR35 & Cystic kidneys & 613602 & CED, SRP & $21473986 ; 20817137$ \\
\hline XPNPEP3 & Nephronophthisis & 613553 & NPHP & 20179356 \\
\hline
\end{tabular}

$A D P K D$ autosomal dominant polycystic kidney disease, $A L S T R$ Alström syndrome, ARPKD autosomal recessive polycystic kidney disease, $A T D$ asphyxiating thoracic dystrophy, $B B S$ Bardet-Biedl syndrome, $C E D$ cranioectodermal dysplasia, $C O A C H$ cerebellar vermis hypo/aplasia, oligophrenia, ataxia, coloboma and hepatic fibrosis, EVC Ellis-van Creveld syndrome, FJHN familial juvenile hyperuricemic nephropathy, GCKD glomerulocystic kidney disease with hyperuricemia and isosthenuria, HYLS hydrolethalus syndrome, JBTS Joubert syndrome, LCA Leber congenital amaurosis, $M C K D$ medullary cystic kidney disease, $M K S$ Meckel-Gruber syndrome, NPHP nephronophthisis, OCRL Lowe oculocerebro-renal syndrome, $O F D$ oro-facio-digital syndrome, $R P$ retinitis pigmentosa, $S G B S$ Simpson-Golabi-Behmel syndrome, $S L S N$ SeniorLøken syndrome, SM Saldino-Mainzer syndrome, SRP short rib polydactyly, TSC tuberous sclerosis, VHL Von Hippel-Lindau disease

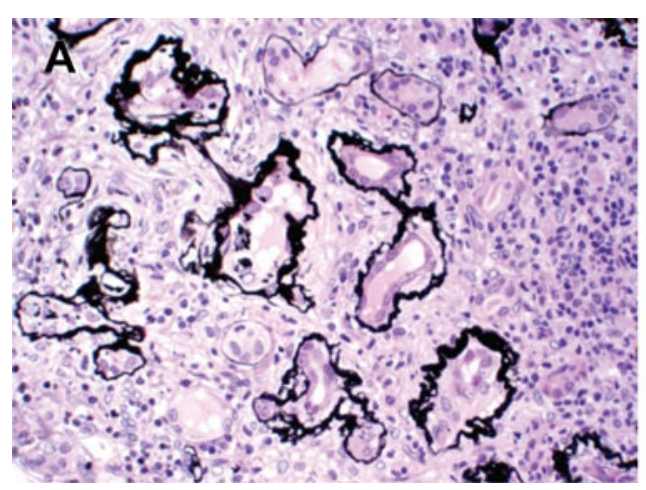

Fig. 2 Nephronophthisis and renal cystic dysplasia. a Pathohistology of nephronophthisis. A cross section through a renal biopsy from a Sensenbrenner patient shows interstitial fibrosis and tubular membrane disruptions (thickened, irregular basement membranes). Image

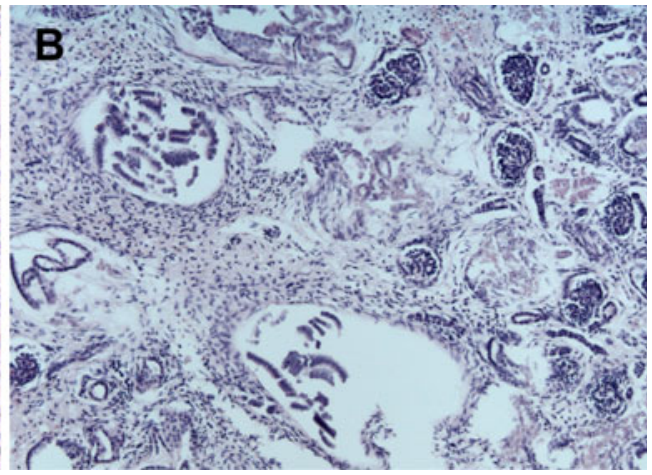

courtesy of Eric Steenbergen. b Cystic dysplastic kidneys with marked interstitial fibrosis and cysts of different sizes form in a fetus with Meckel-Gruber syndrome. Image courtesy of Carsten Bergmann 
Table 2 Phenotype overlap in renal ciliopathies

\begin{tabular}{|c|c|c|c|c|c|c|c|c|c|c|c|}
\hline & BBS & MKS & JBTS & NPHP & SLSN & OFD1 & CED & ATD & SRP & ALSM & PKD \\
\hline Cystic kidneys & $\square$ & $\square$ & $\square$ & $\square$ & $\square$ & $\square$ & $\square$ & $\square$ & $\square$ & $\square$ & $\square$ \\
\hline Hepatobiliary disease & $\square$ & $\square$ & $\square$ & $\square$ & & $\square$ & $\square$ & $\square$ & $\square$ & $\square$ & $\square$ \\
\hline Retinal degeneration & $\square$ & $\square$ & $\square$ & & $\square$ & $\square$ & $\square$ & $\square$ & & $\square$ & \\
\hline Laterality defects & $\square$ & $\square$ & & $\square$ & $\square$ & & & $\square$ & $\square$ & & \\
\hline Intellectual disability & $\square$ & $\square$ & $\square$ & & & $\square$ & & $\square$ & & & \\
\hline Cerebellar vermis hypoplasia & & & $\square$ & & & $\square$ & $\square$ & $\square$ & $\square$ & & \\
\hline Encephalocele & & $\square$ & $\square$ & & & & & & & & \\
\hline Polydactyly & $\square$ & $\square$ & $\square$ & & & $\square$ & $\square$ & $\square$ & $\square$ & & \\
\hline Obesity & $\square$ & & & & & & & & & $\square$ & \\
\hline Shortening/bowing of bones & & $\square$ & & & & & $\square$ & $\square$ & $\square$ & & \\
\hline Ectodermal dysplasia & & & & & & $\square$ & $\square$ & & $\square$ & & \\
\hline
\end{tabular}

$A T D$ asphyxiating thoracic dystrophy (Jeune syndrome), $A L S M$ Alström syndrome, $B B S$ Bardet-Biedl syndrome, $C E D$ cranioectodermal dysplasia (Sensenbrenner syndrome), JBTS, Joubert syndrome, MKS Meckel-Gruber syndrome, NPHP nephronophthisis, OFD1 oro-facio-digital syndrome 1, $P K D$ polycystic kidney disease, SLSN Senior-Løken syndrome, SRP short rib polydactyly syndrome

phenotype relations are thus warranted for better diagnosis and prognosis, and screening for early signs of renal disease is important in most individuals.

From SNP microarray analysis to next-generation sequencing

Although gene defects are still identified through linkage analysis with single nucleotide polymorphism (SNP) microarrays followed by candidate sequencing, e.g., KIF7 associated with acrocallosal, hydrolethalus, and Joubert syndrome [34, 35], CEP41 associated with Joubert syndrome [36], and NEK1 associated with short rib polydactyly [29], nextgeneration sequencing (NGS) techniques are dramatically speeding up gene identification in the ciliopathy field and in the genetics field in general (Fig. 3) [37]. These NGS technologies allow cost-effective and time-efficient gene identification by sequencing large parts or even the full complement of (protein-coding) DNA of a single individual at once. Gene identification can now take a matter of weeks rather than years [38]. Targeted parallel-sequencing of linkage intervals or small groups of genes led to the identification of mutations in the renal ciliopathy genes B9D1 associated with MeckelGruber syndrome [39] and TMEM237 associated with Joubert syndrome [40], while larger-scale ciliopathy candidate exome (ciliome) sequencing led to the detection of mutations in SDCCAG8 [41] and IFT140 [42]. Whole-exome sequencing, whereby all protein-coding DNA (all exons of the genome, $1 \%$ of the genome) is sequenced, has also been applied and resulted in the detection of mutations in WDR35 [22], WDR19 [43], and C5ORF42 [44] as causes of Sensenbrenner and Joubert syndromes respectively. In addition, insights into genotype-phenotype correlations are quickly evolving through parallel-sequencing of a series of known renal ciliopathy genes in large patient cohorts (consisting of roughly 100 500 individuals) [45-47]. This is of great value as this knowledge improves diagnosis, prognosis, and genetic counseling for patients and their relatives.

Dissection of protein complexes facilitates gene identification

Other methods that contribute to gene identification, albeit indirectly, are state-of-the-art proteomic tools, such as tandem affinity purification and yeast two-hybrid assays, that allow dissection of protein networks [14]. Interaction studies taught us that ciliopathy-associated proteins interconnect in a relational ciliopathy protein complex, a dynamic molecular machine that allows ciliary growth and function $[13,15]$. In

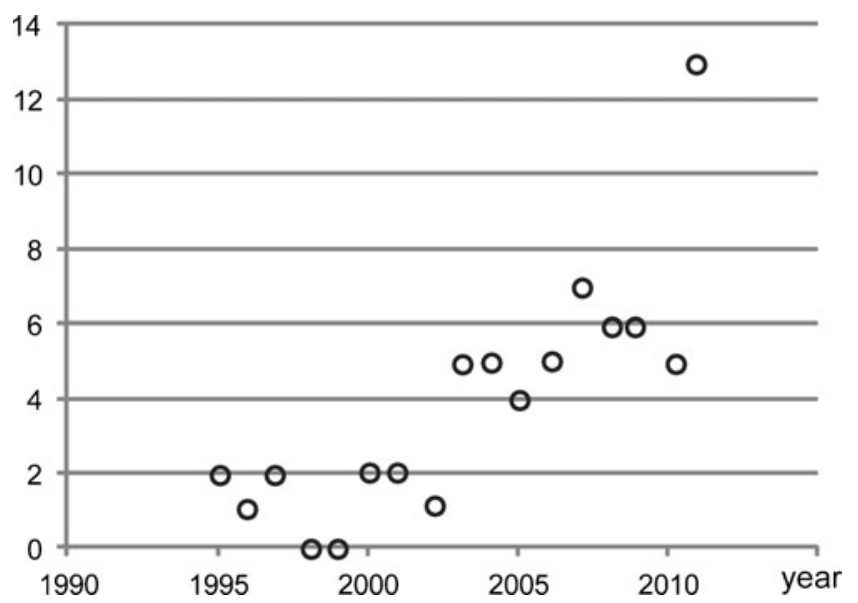

Fig. 3 Gene identification for renal ciliopathies in the period from 1995 to 2011. Open circles indicate the number of genetic causes that were identified in the corresponding year. $\mathrm{X}$-axis: time in years; $\mathrm{y}$-axis: number of genetic causes 
addition, there is ample evidence to conclude that proteins in the ciliopathy network form sub-clusters, which are often associated with distinctive clinical characteristics when mutated. This is illustrated by the following examples. Many of the "nephrocystins" encoded by the nephronophthisis genes physically link together in a "nephrocystin" protein complex (Fig. 1) [14, 48-51]. Similarly, Jackson showed that this is also the case for proteins that are mutated in BardetBiedl syndrome by demonstrating that BBS4 associates with a variety of other BBS proteins (i.e., BBS1, 2, 5, and 7-9), a module that is referred to as the BBSome (Fig. 1) [52]. BBS6, 10 , and 12 were later shown to form a smaller protein complex necessary for the assembly of the BBSome [53]. Consistently, skeletal ciliopathies such as Jeune syndrome, Sensenbrenner syndrome, and short rib polydactyly have almost explicitly been correlated with defects in proteins that form IFT protein complexes (Fig. 1). In 2007, mutations in IFT80 were found to be associated with Jeune syndrome [54], a gene encoding a protein that is part of the multisubunit IFT-B complex; however, almost all other mutations associated with human skeletal ciliopathies occur in genes encoding proteins that are part of the IFT-A complex involved in retrograde transport, i.e., IFT122 [23], WDR35/IFT121 [22, 28], TTC21B/IFT139 [55], WDR19/IFT144 [43], IFT140 [42], IFT43 [56], and DYNC2H1 [57], a subunit of the cytoplasmic dynein motor 2. Taken together, these different (interconnected) protein modules of nephrocystins, BBS proteins, and IFTs are associated with somewhat specific, but overlapping phenotypes [13, 15]. The fact that ciliary proteins form an interaction network insinuates that systematic interaction assays for nephronophthisis-associated proteins may reveal novel candidate disease genes. Excitingly, high-throughput tandem affinity purifications for "nephrocystins" and "Meckel-Gruber-associated proteins" have recently been executed in ciliated cells, and have indeed proven to facilitate gene identification when combined with clinical SNP microarray data from families with ciliopathies; mutations in ATXN10 and TCTN2 were recently identified as the cause of nephronophthisis and Joubert syndrome through this combination of methods [14].

\section{Regulatory mechanisms}

Although it is still challenging to understand how genes are regulated and which noncoding intergenic regions regulate (ciliary) gene expression, this field is evolving as we speak. The Gleeson group recently published an impressive article in Science on gene regulation in Joubert syndrome [58]. As mutations in TMEM216 explained only half of their families with linkage in the JBTS2 locus, they hypothesized that there must be another disease gene in this region. Excitingly, re-sequencing identified mutations in TMEM138, which neighbors TMEM216 head-to-tail (Fig. 4). Both genes appear to be co-regulated by the ciliary transcription factor regulatory factor $\mathrm{X} 4$ (RFX4), a member of the RFX family that consists of at least seven proteins in humans [59], which binds at a noncoding-conserved intergenic region that lies between TMEM138 and TMEM216 (Fig. 4) [58]. It is currently unknown how often nonhomologous, adjacent genes associated with indistinguishable phenotypes share regulatory motifs. As suggested by Gleeson, it will be interesting to determine how transcriptional regulation occurs of the neighboring genes $E V C$ and $E V C 2$, which are mutated in the ciliopathy Ellis-van Creveld syndrome [60]. Generally, co-expression studies will lead toward new insights into the molecular basis of the genetic disorders and may facilitate gene identification and development of targeted therapies for renal ciliopathies.

\section{Genotype-phenotype correlations}

\section{Mutation type}

Mutations in single ciliary genes are often associated with multiple phenotypes. It is generally believed that the nature of the mutations strongly influences the severity of the resulting phenotype, i.e., truncating mutations are associated with more severe phenotypes than missense mutations. However, although this trend is often observed, there are no clear-cut genotype-phenotype correlations, and the fact that clinical differences are often observed between members of single families indicates that the phenotypes also result from modifier effects [3, 4]. It is particularly striking that roughly $40 \%$ of the Joubert syndrome-associated genes, i.e., CC2D2A, CEP290, NPHP3, RPGRIP1L, TCTN2, TMEM216, and TMEM67, are also mutated in the closely related, but more severe, Meckel-Gruber syndrome [4]. Similarly, Sensenbrenner and Jeune syndromes appear to be milder presentations of the embryonically lethal short rib polydactyly syndrome as IFT80, WDR35 and DYNC2H1 are mutated in both milder and more severe phenotypes [22, 28, 54, 57, 61]. Yet, "mild" phenotypes seem to go beyond Sensenbrenner and Jeune syndromes, given the fact that mutations in the IFT genes TTC21B and WDR19 are also associated with isolated nephronophthisis [43, 55]. Future research will show how broad the associated phenotypic spectrum is for the IFT proteins. With respect to the remaining renal ciliopathy genes allelism, which refers to differing phenotypes from different defects in the same gene, is broader than outlined above, and occurs for $30 \%$ of the genes listed in Table 1, which further emphasizes the clinical heterogeneity associated with this group of genes. 


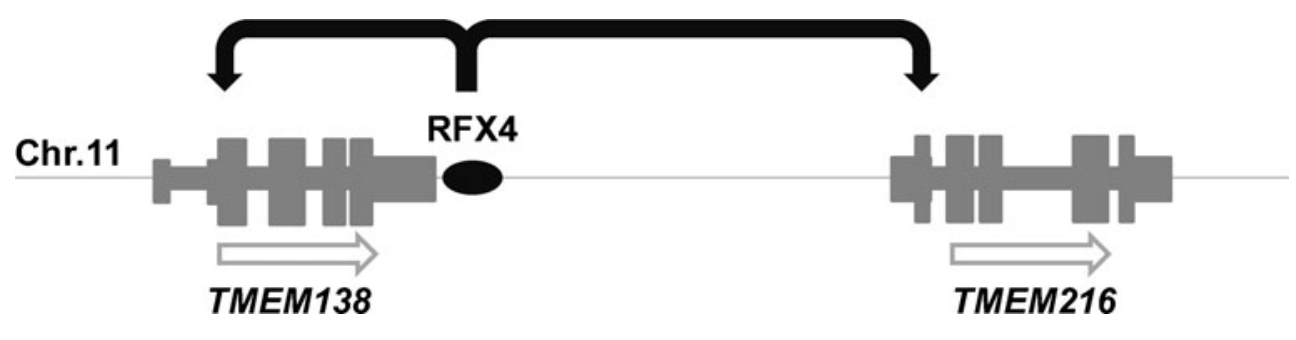

Fig. 4 Gene regulation of two adjacent nonhomologous disease genes. The neighboring TMEM138 and TMEM216, mutated in Joubert syndrome, are regulated by transcription factor RFX4, which binds to a

\section{Mutational load}

Apart from mutation type, "genetic load," "modifier effects," and "oligo-genetic inheritance," which all refer to the possibility that mutations in more than one gene affect the phenotype, have also been proposed as an explanation for the clinical variability within ciliopathies and within families suffering from these disorders. Mutations in multiple genes have been reported in most renal ciliopathies, initially in Bardet-Biedl syndrome $[62,63]$ and later throughout the ciliopathy spectrum $[55,64,65]$. In this respect, there is also exciting news on the dosage theory from the PKD field. Although mutations in PKD1 and $P K D 2$ are associated with dominant disease, it was recently reported that two hypomorphic PKD1 alleles may result in ARPKD-like disease in utero [66]. As the parents of these fetuses had a negative PKD family history, this tells us that it is important to be aware of the possibility that multiple mutations in ADPKD-associated genes can explain renal cystic disease in families with apparently ARPKD. Several other papers describing severe manifestations of PKD also demonstrated that multiple mutations may be present in PKD genes and other genes such as TSC2/HNF1 $\beta$ [67-69]. The "mutational load" theory is thus not only applicable to recessive renal ciliopathies, but also to dominant renal cystic disorders.

\section{New ciliopathies}

New ciliopathies can be uncovered in different ways. Baker and Beales accurately predicted that various syndromes such as Jeune asphyxiating thoracic dystrophy, Sensenbrenner syndrome (also known as cranioectodermal dysplasia), and Saldino-Mainzer syndrome belong to the ciliopathy spectrum [20]. Their analysis was based on screening for (multiple) classic ciliopathy features in the Online Mendelian Inheritance in Man (OMIM) clinical database. Besides comparing human phenotypes, we can also extract predictive markers for human disease from studies with mouse mutants; there are for instance clues from a conditional noncoding conserved regulatory intergenic region (black oval). Open arrows indicate that both genes are located on the sense strand of chromosome 11

murine Kif3a mutant that frontonasal dysplasia could be the result of ciliary dysfunction [70-72]. Finally, identification of novel ciliary functions for proteins associated with human disease may reveal that the molecular cause of disease may be (in part) due to ciliary disruption, thereby opening avenues for development of targeted therapies. A recent example is a publication from Coon et al. on Lowe syndrome [73]. This syndrome is a cerebrorenal developmental disorder that is characterized by Dent's disease in the kidney, a renal proximal tubulopathy. The association of defective cilia with this syndrome and the fact that Dent's disease has not previously been associated with ciliary dysfunction raises the question whether there are more patients with this renal phenotype with mutations in different genes that encode proteins involved in the biology of renal cilia.

\section{Next-generation sequencing and clinical perspectives}

Currently, NGS is mostly used for research purposes to identify novel disease genes and to gain more insights into genotype-phenotype correlations in a time- and costeffective effort. The power of NGS has proven itself in research laboratories, and in the coming years this technology will be implemented in DNA diagnostic laboratories throughout the world. Whereas disease genes are currently stepwise Sanger sequenced in diagnostics based on an educated guess at the best candidate gene, whereby clinical phenotype, mutation frequency, and ethnic origin are considered, unbiased mutation screening through NGS is expected to be much more effective [3]. Although NGS will improve diagnosis, prognosis, and genetic counseling for patients in daily clinical practice, there are also challenges for the implementation of this technology in DNA diagnostics [74]. Data interpretation must be focused on finding mutations in known genes, thus requiring the development of new software for data analysis. Excellent bioinformaticians and infrastructures are a necessity for NGS data management and analysis. The latter is a bottleneck in research, and will be an even more prominent problem in DNA diagnostics, as the accuracy of mutation detection is more important in the clinic, 
raising questions on how to handle poor sequence coverage for selected genomic regions in a diagnostic setting. Aside from the technical challenges, the ethical implications of NGS are enormous $[75,76]$. For instance, NGS may identify mutations in genes unrelated to the studied disease, which has major implications for patients and their relatives. Concerning renal ciliopathies, should we sequence exomes or a selected set of known ciliopathy genes to avoid the latter? What to do with variants of unknown significance? What should be the content of a consent form, especially with respect to unanticipated mutations? Whose consent should be asked, given that NGS findings could also have a major impact on the lives of family members? These are just a few of the long list of ethical issues that remain to be resolved.

\section{Roads to therapy}

Once end-stage renal disease develops, patients with renal ciliopathies currently depend on invasive therapies such as hemodialysis or renal replacement strategies, which have a major impact on the quality of life for patients and their relatives. The development of targeted therapies is thus warranted. In this respect significant progress has been made in the (AD)PKD field. Several clinical trials are underway, some are finished, and potential drug targets are continuously being identified in rodent models [77-84]. Because the PKD- and nephronophthisis-associated genes are involved in similar ciliary pathways, PKD treatment may eventually also appear to be valuable for nephronophthisis patients. Targeted therapy development for nephronophthisis has fallen behind in comparison to that for PKD, likely because of the lower prevalence and enormous genetic heterogeneity associated with this disorder. Fortunately, the NGS-accelerated identification of genetic defects in nephronophthisis opens a window of opportunity for the development of (personalized) therapies, as insights into disease mechanisms are increased and targeted drug screens become possible. Notably, cost- and time-effective small molecule screening in zebrafish is expected to contribute to drug discovery $[85,86]$ and various mouse models are already being tested for selected compounds [87]. Furthermore, the development of the induced pluripotent stem cell (iPSC) technology allows drug screening in a patient's own cells and may hold promise for future tissue regeneration therapy $[88,89]$. Although many studies are focused on the treatment and prevention of PKD, the first stones in the path toward targeted therapy development for nephronophthisis are only just beginning to be laid. Yet, with the recent development of NGS we now have the chance to remedy this situation by rapidly exposing potential treatment targets, and by using this information for personalized medicine.

\section{Conclusions}

We are well on our way to identifying the genetic mechanisms underlying the renal ciliopathies. NGS methods are accelerating this process enormously, and massive parallelsequencing genetic tests will soon be available for routine diagnostic screening. The availability of such tests will improve diagnostics, prognosis, and genetic counseling tremendously; however, challenges in bioinformatic analysis and variant interpretation remain, as well as the requirement of strict ethical regulations. Besides genetic progress, molecular studies in ciliated (patient) cell lines and model organisms expanded our insights of the disease mechanisms of nephronophthisis and associated disorders. The next challenge is to use this genetic and molecular knowledge toward the development of targeted (personalized) therapies to delay and preferably prevent the progressive degenerative effects of nephronophthisis in patients.

Acknowledgements We thank the Dutch Kidney Foundation for funding (KJBP09.009 and IP11.58 to HHA). We also thank Dr. Nicole van de Kar for discussions, and Dr. Eric Steenbergen and Dr. Carsten Bergmann for Fig. 2a and $\mathrm{b}$ respectively.

Open Access This article is distributed under the terms of the Creative Commons Attribution License which permits any use, distribution, and reproduction in any medium, provided the original author(s) and the source are credited.

\section{References}

1. Dobell C (1932) Antony van Leeuwenhoek and his 'Little Animals'. Swets \& Zeitlinger, Amsterdam, p 135

2. Bloodgood RA (2009) From central to rudimentary to primary: the history of an underappreciated organelle whose time has come. The primary cilium. In: Sloboda RD (ed) Primary cilia. Elsevier, Amsterdam, p 4

3. Bergmann C (2011) Educational paper: ciliopathies. Eur J Pediatr. doi:10.1007/s00431-011-1553-z

4. Hildebrandt F, Benzing T, Katsanis N (2011) Ciliopathies. N Engl J Med 364:1533-1543

5. Ishikawa H, Marshall WF (2011) Ciliogenesis: building the cell's antenna. Nat Rev Mol Cell Biol 12:222-234

6. Piperno G, Siuda E, Henderson S, Segil M, Vaananen H, Sassaroli M (1998) Distinct mutants of retrograde intraflagellar transport (IFT) share similar morphological and molecular defects. J Cell Biol 143:1591-1601

7. Pazour GJ, Dickert BL, Vucica Y, Seeley ES, Rosenbaum JL, Witman GB, Cole DG (2000) Chlamydomonas IFT88 and its mouse homologue, polycystic kidney disease gene tg737, are required for assembly of cilia and flagella. J Cell Biol 151:709-718

8. Hurd TW, Hildebrandt F (2011) Mechanisms of nephronophthisis and related ciliopathies. Nephron Exp Nephrol 118:e9-e14

9. Hildebrandt F, Otto E, Rensing C, Nothwang HG, Vollmer M, Adolphs J, Hanusch H, Brandis M (1997) A novel gene encoding an $\mathrm{SH} 3$ domain protein is mutated in nephronophthisis type 1. Nat Genet 17:149-153

10. Caridi G, Dagnino M, Rossi A, Valente EM, Bertini E, Fazzi E, Emma F, Murer L, Verrina E, Ghiggeri GM (2006) Nephronophthisis 
type 1 deletion syndrome with neurological symptoms: prevalence and significance of the association. Kidney Int 70:1342-1347

11. Castori M, Valente EM, Donati MA, Salvi S, Fazzi E, Procopio E, Galluccio T, Emma F, Dallapiccola B, Bertini E (2005) NPHP1 gene deletion is a rare cause of Joubert syndrome related disorders. J Med Genet 42:e9

12. Parisi MA, Bennett CL, Eckert ML, Dobyns WB, Gleeson JG, Shaw DW, McDonald R, Eddy A, Chance PF, Glass IA (2004) The NPHP1 gene deletion associated with juvenile nephronophthisis is present in a subset of individuals with Joubert syndrome. Am J Hum Genet 75:82-91

13. Novarino G, Akizu N, Gleeson JG (2011) Modeling human disease in humans: the ciliopathies. Cell 147:70-79

14. Sang L, Miller JJ, Corbit KC, Giles RH, Brauer MJ, Otto EA, Baye LM, Wen X, Scales SJ, Kwong M, Huntzicker EG, Sfakianos MK, Sandoval W, Bazan JF, Kulkarni P, Garcia-Gonzalo FR, Seol AD, O'Toole JF, Held S, Reutter HM, Lane WS, Rafiq MA, Noor A, Ansar M, Devi AR, Sheffield VC, Slusarski DC, Vincent JB, Doherty DA, Hildebrandt F, Reiter JF, Jackson PK (2011) Mapping the NPHP-JBTS-MKS protein network reveals ciliopathy disease genes and pathways. Cell 145:513-528

15. Van Reeuwijk J, Arts HH, Roepman R (2011) Scrutinizing ciliopathies by unraveling ciliary interaction networks. Hum Mol Genet 20:R149-R157

16. Delous M, Hellman NE, Gaude HM, Silbermann F, Le BA, Salomon R, Antignac C, Saunier S (2009) Nephrocystin-1 and nephrocystin-4 are required for epithelial morphogenesis and associate with PALS1/ PATJ and Par6. Hum Mol Genet 18:4711-4723

17. Attanasio M, Uhlenhaut NH, Sousa VH, O'Toole JF, Otto E, Anlag K, Klugmann C, Treier AC, Helou J, Sayer JA, Seelow D, Nurnberg G, Becker C, Chudley AE, Nurnberg P, Hildebrandt F, Treier M (2007) Loss of GLIS2 causes nephronophthisis in humans and mice by increased apoptosis and fibrosis. Nat Genet 39:1018-1024

18. Nurnberger J, Bacallao RL, Phillips CL (2002) Inversin forms a complex with catenins and N-cadherin in polarized epithelial cells. Mol Biol Cell 13:3096-3106

19. O'Toole JF, Liu Y, Davis EE, Westlake CJ, Attanasio M, Otto EA, Seelow D, Nurnberg G, Becker C, Nuutinen M, Karppa M, Ignatius J, Uusimaa J, Pakanen S, Jaakkola E, van den Heuvel LP, Fehrenbach H, Wiggins R, Goyal M, Zhou W, Wolf MT, Wise E, Helou J, Allen SJ, Murga-Zamalloa CA, Ashraf S, Chaki M, Heeringa S, Chernin G, Hoskins BE, Chaib H, Gleeson J, Kusakabe T, Suzuki T, Isaac RE, Quarmby LM, Tennant B, Fujioka H, Tuominen H, Hassinen I, Lohi H, van Houten JL, Rotig A, Sayer JA, Rolinski B, Freisinger P, Madhavan SM, Herzer M, Madignier F, Prokisch H, Nurnberg P, Jackson PK, Khanna H, Katsanis N, Hildebrandt F (2010) Individuals with mutations in XPNPEP3, which encodes a mitochondrial protein, develop a nephronophthisis-like nephropathy. J Clin Invest 120:791-802

20. Baker K, Beales PL (2009) Making sense of cilia in disease: the human ciliopathies. Am J Med Genet C Semin Med Genet 151C:281-295

21. Konstantinidou AE, Fryssira H, Sifakis S, Karadimas C, Kaminopetros P, Agrogiannis G, Velonis S, Nikkels PG, Patsouris E (2009) Cranioectodermal dysplasia: a probable ciliopathy. Am J Med Genet A 149A:2206-2211

22. Gilissen C, Arts HH, Hoischen A, Spruijt L, Mans DA, Arts P, van Lier B, Steehouwer M, van Reeuwijk J, Kant SG, Roepman R, Knoers NV, Veltman JA, Brunner HG (2010) Exome sequencing identifies WDR35 variants involved in Sensenbrenner syndrome. Am J Hum Genet 87:418-423

23. Walczak-Sztulpa J, Eggenschwiler J, Osborn D, Brown DA, Emma F, Klingenberg C, Hennekam RC, Torre G, Garshasbi M, Tzschach A, Szczepanska M, Krawczynski M, Zachwieja J, Zwolinska D, Beales PL, Ropers HH, Latos-Bielenska A, Kuss AW (2010) Cranioectodermal dysplasia, Sensenbrenner syndrome, is a ciliopathy caused by mutations in the IFT122 gene. Am J Hum Genet 86:949-956

24. Fry AE, Klingenberg C, Matthes J, Heimdal K, Hennekam RC, Pilz DT (2009) Connective tissue involvement in two patients with features of cranioectodermal dysplasia. Am J Med Genet A 149A:2212-2215

25. Levin LS, Perrin JC, Ose L, Dorst JP, Miller JD, McKusick VA (1977) A heritable syndrome of craniosynostosis, short thin hair, dental abnormalities, and short limbs: cranioectodermal dysplasia. J Pediatr 90:55-61

26. Sensenbrenner JA, Dorst JP, Owens RP (1975) New syndrome of skeletal, dental and hair anomalies. Birth Defects Orig Artic Ser 11:372-379

27. Mecke S, Passarge E (1971) Encephalocele, polycystic kidneys, and polydactyly as an autosomal recessive trait simulating certain other disorders: the Meckel syndrome. Ann Genet 14:97-103

28. Mill P, Lockhart PJ, Fitzpatrick E, Mountford HS, Hall EA, Reijns MA, Keighren M, Bahlo M, Bromhead CJ, Budd P, Aftimos S, Delatycki MB, Savarirayan R, Jackson IJ, Amor DJ (2011) Human and mouse mutations in WDR35 cause short-rib polydactyly syndromes due to abnormal ciliogenesis. Am J Hum Genet 88:508-515

29. Thiel C, Kessler K, Giessl A, Dimmler A, Shalev SA, von der Haar HS, Zenker M, Zahnleiter D, Stoss H, Beinder E, Abou JR, Ekici AB, Schroder-Kress N, Aigner T, Kirchner T, Reis A, Brandstatter JH, Rauch A (2011) NEK1 mutations cause short-rib polydactyly syndrome type majewski. Am J Hum Genet 88:106-114

30. Tallila J, Jakkula E, Peltonen L, Salonen R, Kestila M (2008) Identification of CC2D2A as a Meckel syndrome gene adds an important piece to the ciliopathy puzzle. Am J Hum Genet 82:1361-1367

31. Slavotinek AM, Stone EM, Mykytyn K, Heckenlively JR, Green JS, Heon E, Musarella MA, Parfrey PS, Sheffield VC, Biesecker LG (2000) Mutations in MKKS cause Bardet-Biedl syndrome. Nat Genet 26:15-16

32. Beales PL, Warner AM, Hitman GA, Thakker R, Flinter FA (1997) Bardet-Biedl syndrome: a molecular and phenotypic study of 18 families. J Med Genet 34:92-98

33. Fan Y, Esmail MA, Ansley SJ, Blacque OE, Boroevich K, Ross AJ, Moore SJ, Badano JL, May-Simera H, Compton DS, Green JS, Lewis RA, van Haelst MM, Parfrey PS, Baillie DL, Beales PL, Katsanis N, Davidson WS, Leroux MR (2004) Mutations in a member of the Ras superfamily of small GTP-binding proteins causes Bardet-Biedl syndrome. Nat Genet 36:989-993

34. Dafinger C, Liebau MC, Elsayed SM, Hellenbroich Y, Boltshauser E, Korenke GC, Fabretti F, Janecke AR, Ebermann I, Nurnberg G, Nurnberg P, Zentgraf H, Koerber F, Addicks K, Elsobky E, Benzing T, Schermer B, Bolz HJ (2011) Mutations in KIF7 link Joubert syndrome with Sonic Hedgehog signaling and microtubule dynamics. J Clin Invest 121:2662-2667

35. Putoux A, Thomas S, Coene KL, Davis EE, Alanay Y, Ogur G, Uz E, Buzas D, Gomes C, Patrier S, Bennett CL, Elkhartoufi N, Frison MH, Rigonnot L, Joye N, Pruvost S, Utine GE, Boduroglu K, Nitschke P, Fertitta L, Thauvin-Robinet C, Munnich A, Cormier-Daire V, Hennekam R, Colin E, Akarsu NA, Bole-Feysot C, Cagnard N, Schmitt A, Goudin N, Lyonnet S, Encha-Razavi F, Siffroi JP, Winey M, Katsanis N, Gonzales M, Vekemans M, Beales PL, Attie-Bitach T (2011) KIF7 mutations cause fetal hydrolethalus and acrocallosal syndromes. Nat Genet 43:601-606

36. Lee JE, Silhavy JL, Zaki MS, Schroth J, Bielas SL, Marsh SE, Olvera J, Brancati F, Iannicelli M, Ikegami K, Schlossman AM, Merriman B, Attie-Bitach T, Logan CV, Glass IA, Cluckey A, Louie CM, Lee JH, Raynes HR, Rapin I, Castroviejo IP, Setou M, Barbot C, Boltshauser E, Nelson SF, Hildebrandt F, Johnson CA, Doherty DA, Valente EM, Gleeson JG (2012) CEP41 is mutated in Joubert syndrome and is required for tubulin glutamylation at the cilium. Nat Genet 44:193-199 
37. Gilissen C, Hoischen A, Brunner HG, Veltman JA (2012) Disease gene identification strategies for exome sequencing. Eur J Hum Genet 20:490-497

38. Bamshad MJ, Ng SB, Bigham AW, Tabor HK, Emond MJ, Nickerson DA, Shendure J (2011) Exome sequencing as a tool for Mendelian disease gene discovery. Nat Rev Genet 12:745-755

39. Hopp K, Heyer CM, Hommerding CJ, Henke SA, Sundsbak JL, Patel S, Patel P, Consugar MB, Czarnecki PG, Gliem TJ, Torres VE, Rossetti S, Harris PC (2011) B9D1 is revealed as a novel Meckel syndrome (MKS) gene by targeted exon-enriched nextgeneration sequencing and deletion analysis. Hum Mol Genet 20:2525-2534

40. Huang L, Szymanska K, Jensen VL, Janecke AR, Innes AM, Davis EE, Frosk P, Li C, Willer JR, Chodirker BN, Greenberg CR, McLeod DR, Bernier FP, Chudley AE, Muller T, Shboul M, Logan CV, Loucks CM, Beaulieu CL, Bowie RV, Bell SM, Adkins J, Zuniga FI, Ross KD, Wang J, Ban MR, Becker C, Nurnberg P, Douglas S, Craft CM, Akimenko MA, Hegele RA, Ober C, Utermann G, Bolz HJ, Bulman DE, Katsanis N, Blacque OE, Doherty D, Parboosingh JS, Leroux MR, Johnson CA, Boycott KM (2011) TMEM237 is mutated in individuals with a Joubert syndrome related disorder and expands the role of the TMEM family at the ciliary transition zone. Am J Hum Genet 89:713-730

41. Otto EA, Hurd TW, Airik R, Chaki M, Zhou W, Stoetzel C, Patil SB, Levy S, Ghosh AK, Murga-Zamalloa CA, van Reeuwijk J, Letteboer SJ, Sang L, Giles RH, Liu Q, Coene KL, Estrada-Cuzcano A, Collin RW, McLaughlin HM, Held S, Kasanuki JM, Ramaswami G, Conte J, Lopez I, Washburn J, Macdonald J, Hu J, Yamashita Y, Maher ER, Guay-Woodford LM, Neumann HP, Obermuller N, Koenekoop RK, Bergmann C, Bei X, Lewis RA, Katsanis N, Lopes V, Williams DS, Lyons RH, Dang CV, Brito DA, Dias MB, Zhang X, Cavalcoli JD, Nurnberg G, Nurnberg P, Pierce EA, Jackson PK, Antignac C, Saunier S, Roepman R, Dollfus H, Khanna H, Hildebrandt F (2010) Candidate exome capture identifies mutation of SDCCAG8 as the cause of a retinal-renal ciliopathy. Nat Genet 42:840-850

42. Perrault I, Saunier S, Hanein S, Filhol E, Bizet A, Collins F, Salih MAM, Gerber S, Delphin N, Bigot K, Orssaud C, Silva E, Baudouin V, Oud MM, Shannon N, Le Merrer M, Roche R, Pietrement C, Goumid J, Baumann C, Bole-Feysot C, Nitschke P, Zahrate M, Beales P, Arts HH, Munnich A, Kaplan J, Antignac C, CormierDaire V, Rozet J (2012) Mainzer-Saldino syndrome is a ciliopathy caused by IFT140 mutations. Am J Hum Genet 90:864-870

43. Bredrup C, Saunier S, Oud MM, Fiskerstrand T, Hoischen A, Brackman D, Leh SM, Midtbo M, Filhol E, Bole-Feysot C, Nitschke P, Gilissen C, Haugen OH, Sanders JS, Stolte-Dijkstra I, Mans DA, Steenbergen EJ, Hamel BC, Matignon M, Pfundt R, Jeanpierre C, Boman H, Rodahl E, Veltman JA, Knappskog PM, Knoers NV, Roepman R, Arts HH (2011) Ciliopathies with skeletal anomalies and renal insufficiency due to mutations in the IFT-A gene WDR19. Am J Hum Genet 89:634-643

44. Srour M, Schwartzentruber J, Hamdan FF, Ospina LH, Patry L, Labuda D, Massicotte C, Dobrzeniecka S, Capo-Chichi JM, Papillon-Cavanagh S, Samuels ME, Boycott KM, Shevell MI, Laframboise R, Desilets V, Maranda B, Rouleau GA, Majewski J, Michaud JL (2012) Mutations in C5ORF42 cause Joubert Syndrome in the French Canadian population. Am J Hum Genet 90:693-700

45. Otto EA, Ramaswami G, Janssen S, Chaki M, Allen SJ, Zhou W, Airik R, Hurd TW, Ghosh AK, Wolf MT, Hoppe B, Neuhaus TJ, Bockenhauer D, Milford DV, Soliman NA, Antignac C, Saunier S, Johnson CA, Hildebrandt F (2011) Mutation analysis of 18 nephronophthisis associated ciliopathy disease genes using a DNA pooling and next generation sequencing strategy. J Med Genet 48:105-116

46. Janssen S, Ramaswami G, Davis EE, Hurd T, Airik R, Kasanuki JM, Van Der Kraak L, Allen SJ, Beales PL, Katsanis N, Otto EA,
Hildebrandt F (2011) Mutation analysis in Bardet-Biedl syndrome by DNA pooling and massively parallel resequencing in 105 individuals. Hum Genet 129:79-90

47. Chaki M, Hoefele J, Allen SJ, Ramaswami G, Janssen S, Bergmann C, Heckenlively JR, Otto EA, Hildebrandt F (2011) Genotypephenotype correlation in 440 patients with NPHP-related ciliopathies. Kidney Int 80:1239-1245

48. Olbrich H, Fliegauf M, Hoefele J, Kispert A, Otto E, Volz A, Wolf MT, Sasmaz G, Trauer U, Reinhardt R, Sudbrak R, Antignac C, Gretz N, Walz G, Schermer B, Benzing T, Hildebrandt F, Omran H (2003) Mutations in a novel gene, NPHP3, cause adolescent nephronophthisis, tapeto-retinal degeneration and hepatic fibrosis. Nat Genet 34:455-459

49. Schafer T, Putz M, Lienkamp S, Ganner A, Bergbreiter A, Ramachandran H, Gieloff V, Gerner M, Mattonet C, Czarnecki PG, Sayer JA, Otto EA, Hildebrandt F, Kramer-Zucker A, Walz G (2008) Genetic and physical interaction between the NPHP5 and NPHP6 gene products. Hum Mol Genet 17:3655-3662

50. Mollet G, Salomon R, Gribouval O, Silbermann F, Bacq D, Landthaler G, Milford D, Nayir A, Rizzoni G, Antignac C, Saunier S (2002) The gene mutated in juvenile nephronophthisis type 4 encodes a novel protein that interacts with nephrocystin. Nat Genet 32:300-305

51. Otto EA, Schermer B, Obara T, O'Toole JF, Hiller KS, Mueller AM, Ruf RG, Hoefele J, Beekmann F, Landau D, Foreman JW, Goodship JA, Strachan T, Kispert A, Wolf MT, Gagnadoux MF, Nivet H, Antignac C, Walz G, Drummond IA, Benzing T, Hildebrandt F (2003) Mutations in INVS encoding inversin cause nephronophthisis type 2 , linking renal cystic disease to the function of primary cilia and left-right axis determination. Nat Genet 34:413-420

52. Nachury MV, Loktev AV, Zhang Q, Westlake CJ, Peranen J, Merdes A, Slusarski DC, Scheller RH, Bazan JF, Sheffield VC, Jackson PK (2007) A core complex of BBS proteins cooperates with the GTPase Rab8 to promote ciliary membrane biogenesis. Cell 129:1201-1213

53. Seo S, Baye LM, Schulz NP, Beck JS, Zhang Q, Slusarski DC, Sheffield VC (2010) BBS6, BBS10, and BBS12 form a complex with CCT/TRiC family chaperonins and mediate BBSome assembly. Proc Natl Acad Sci U S A 107:1488-1493

54. Beales PL, Bland E, Tobin JL, Bacchelli C, Tuysuz B, Hill J, Rix S, Pearson CG, Kai M, Hartley J, Johnson C, Irving M, Elcioglu N, Winey M, Tada M, Scambler PJ (2007) IFT80, which encodes a conserved intraflagellar transport protein, is mutated in Jeune asphyxiating thoracic dystrophy. Nat Genet 39:727-729

55. Davis EE, Zhang Q, Liu Q, Diplas BH, Davey LM, Hartley J, Stoetzel C, Szymanska K, Ramaswami G, Logan CV, Muzny DM, Young AC, Wheeler DA, Cruz P, Morgan M, Lewis LR, Cherukuri P, Maskeri B, Hansen NF, Mullikin JC, Blakesley RW, Bouffard GG, Gyapay G, Rieger S, Tonshoff B, Kern I, Soliman NA, Neuhaus TJ, Swoboda KJ, Kayserili H, Gallagher TE, Lewis RA, Bergmann C, Otto EA, Saunier S, Scambler PJ, Beales PL, Gleeson JG, Maher ER, Attie-Bitach T, Dollfus H, Johnson CA, Green ED, Gibbs RA, Hildebrandt F, Pierce EA, Katsanis N (2011) TTC21B contributes both causal and modifying alleles across the ciliopathy spectrum. Nat Genet 43:189-196

56. Arts HH, Bongers EM, Mans DA, van Beersum SE, Oud MM, Bolat E, Spruijt L, Cornelissen EA, Schuurs-Hoeijmakers JH, de Leeuw N, Cormier-Daire V, Brunner HG, Knoers NV, Roepman R (2011) C14ORF179 encoding IFT43 is mutated in Sensenbrenner syndrome. J Med Genet 48:390-395

57. Dagoneau N, Goulet M, Genevieve D, Sznajer Y, Martinovic J, Smithson S, Huber C, Baujat G, Flori E, Tecco L, Cavalcanti D, Delezoide AL, Serre V, Le Merrer M, Munnich A, Cormier-Daire V (2009) DYNC2H1 mutations cause asphyxiating thoracic dystrophy and short rib-polydactyly syndrome, type III. Am J Hum Genet 84:706-711 
58. Lee JH, Silhavy JL, Lee JE, Al-Gazali L, Thomas S, Davis EE, Bielas SL, Hill KJ, Iannicelli M, Brancati F, Gabriel SB, Russ C, Logan CV, Sharif SM, Bennett CP, Abe M, Hildebrandt F, Diplas BH, AttieBitach T, Katsanis N, Rajab A, Koul R, Sztriha L, Waters ER, FerroNovick S, Woods CG, Johnson CA, Valente EM, Zaki MS, Gleeson JG (2012) Evolutionarily assembled cis-regulatory module at a human ciliopathy locus. Science 335:966-969

59. Aftab S, Semenec L, Chu JS, Chen N (2008) Identification and characterization of novel human tissue-specific RFX transcription factors. BMC Evol Biol 8:226

60. Ruiz-Perez VL, Tompson SW, Blair HJ, Espinoza-Valdez C, Lapunzina P, Silva EO, Hamel B, Gibbs JL, Young ID, Wright MJ, Goodship JA (2003) Mutations in two nonhomologous genes in a head-to-head configuration cause Ellis-van Creveld syndrome. Am J Hum Genet 72:728-732

61. Cavalcanti DP, Huber C, Sang KH, Baujat G, Collins F, Delezoide AL, Dagoneau N, Le Merrer M, Martinovic J, Mello MF, Vekemans M, Munnich A, Cormier-Daire V (2011) Mutation in IFT80 in a fetus with the phenotype of Verma-Naumoff provides molecular evidence for Jeune-Verma-Naumoff dysplasia spectrum. J Med Genet 48:88-92

62. Badano JL, Kim JC, Hoskins BE, Lewis RA, Ansley SJ, Cutler DJ, Castellan C, Beales PL, Leroux MR, Katsanis N (2003) Heterozygous mutations in BBS1, BBS2 and BBS6 have a potential epistatic effect on Bardet-Biedl patients with two mutations at a second BBS locus. Hum Mol Genet 12:1651-1659

63. Beales PL, Badano JL, Ross AJ, Ansley SJ, Hoskins BE, Kirsten B, Mein CA, Froguel P, Scambler PJ, Lewis RA, Lupski JR, Katsanis N (2003) Genetic interaction of BBS1 mutations with alleles at other BBS loci can result in non-Mendelian Bardet-Biedl syndrome. Am J Hum Genet 72:1187-1199

64. Leitch CC, Zaghloul NA, Davis EE, Stoetzel C, Diaz-Font A, Rix S, Alfadhel M, Lewis RA, Eyaid W, Banin E, Dollfus H, Beales PL, Badano JL, Katsanis N (2008) Hypomorphic mutations in syndromic encephalocele genes are associated with Bardet-Biedl syndrome. Nat Genet 40:443-448

65. Tory K, Lacoste T, Burglen L, Moriniere V, Boddaert N, Macher MA, Llanas B, Nivet H, Bensman A, Niaudet P, Antignac C, Salomon R, Saunier S (2007) High NPHP1 and NPHP6 mutation rate in patients with Joubert syndrome and nephronophthisis: potential epistatic effect of NPHP6 and AHI1 mutations in patients with NPHP1 mutations. J Am Soc Nephrol 18:1566-1575

66. Vujic M, Heyer CM, Ars E, Hopp K, Markoff A, Orndal C, Rudenhed B, Nasr SH, Torres VE, Torra R, Bogdanova N, Harris PC (2010) Incompletely penetrant PKD1 alleles mimic the renal manifestations of ARPKD. J Am Soc Nephrol 21:1097-1102

67. Bergmann C, von Bothmer J, Ortiz BN, Venghaus A, Frank V, Fehrenbach H, Hampel T, Pape L, Buske A, Jonsson J, Sarioglu N, Santos A, Ferreira JC, Becker JU, Cremer R, Hoefele J, Benz MR, Weber LT, Buettner R, Zerres K (2011) Mutations in multiple PKD genes may explain early and severe polycystic kidney disease. J Am Soc Nephrol 22:2047-2056

68. Dedoussis GV, Luo Y, Starremans P, Rossetti S, Ramos AJ, Cantiello HF, Katsareli E, Ziroyannis P, Lamnissou K, Harris PC, Zhou J (2008) Co-inheritance of a PKD1 mutation and homozygous PKD2 variant: a potential modifier in autosomal dominant polycystic kidney disease. Eur J Clin Invest 38:180-190

69. Losekoot M, Ruivenkamp CA, Tholens AP, Grimbergen JE, Vijfhuizen L, Vermeer S, Dijkman HB, Cornelissen EA, Bongers EM, Peters DJ (2012) Neonatal onset autosomal dominant polycystic kidney disease (ADPKD) in a patient homozygous for a PKD2 missense mutation due to uniparental disomy. J Med Genet 49:37-40

70. Friedland-Little JM, Hoffmann AD, Ocbina PJ, Peterson MA, Bosman JD, Chen Y, Cheng SY, Anderson KV, Moskowitz IP (2011) A novel murine allele of Intraflagellar Transport Protein 172 causes a syndrome including VACTERL-like features with hydrocephalus. Hum Mol Genet 20:3725-3737
71. Ermakov A, Stevens JL, Whitehill E, Robson JE, Pieles G, Brooker D, Goggolidou P, Powles-Glover N, Hacker T, Young SR, Dear N, Hirst E, Tymowska-Lalanne Z, Briscoe J, Bhattacharya S, Norris DP (2009) Mouse mutagenesis identifies novel roles for left-right patterning genes in pulmonary, craniofacial, ocular, and limb development. Dev Dyn 238:581-594

72. Brugmann SA, Cordero DR, Helms JA (2010) Craniofacial ciliopathies: a new classification for craniofacial disorders. Am J Med Genet A 152A:2995-3006

73. Coon BG, Hernandez V, Madhivanan K, Mukherjee D, Hanna CB, Barinaga-Rementeria RI, Lowe M, Beales PL, Aguilar RC (2012) The Lowe syndrome protein OCRL1 is involved in primary cilia assembly. Hum Mol Genet 21:1835-1847

74. Desai AN, Jere A (2012) Next generation sequencing: ready for the clinics? Clin Genet 81:503-510

75. Tabor HK, Stock J, Brazg T, McMillin MJ, Dent KM, Yu JH, Shendure J, Bamshad MJ (2012) Informed consent for whole genome sequencing: a qualitative analysis of participant expectations and perceptions of risks, benefits, and harms. Am J Med Genet A 158A:1310-1319

76. Tabor HK, Berkman BE, Hull SC, Bamshad MJ (2011) Genomics really gets personal: how exome and whole genome sequencing challenge the ethical framework of human genetics research. Am J Med Genet A 155A:2916-2924

77. Caroli A, Antiga L, Cafaro M, Fasolini G, Remuzzi A, Remuzzi G, Ruggenenti P (2010) Reducing polycystic liver volume in ADPKD: effects of somatostatin analogue octreotide. Clin J Am Soc Nephrol 5:783-789

78. Hogan MC, Masyuk TV, Page LJ, Kubly VJ, Bergstralh EJ, Li X, Kim B, King BF, Glockner J, Holmes DR III, Rossetti S, Harris PC, LaRusso NF, Torres VE (2010) Randomized clinical trial of long-acting somatostatin for autosomal dominant polycystic kidney and liver disease. J Am Soc Nephrol 21:1052-1061

79. Ibraghimov-Beskrovnaya O, Natoli TA (2011) mTOR signaling in polycystic kidney disease. Trends Mol Med 17:625-633

80. Park EY, Woo YM, Park JH (2011) Polycystic kidney disease and therapeutic approaches. BMB Rep 44:359-368

81. Qian Q, Du H, King BF, Kumar S, Dean PG, Cosio FG, Torres VE (2008) Sirolimus reduces polycystic liver volume in ADPKD patients. J Am Soc Nephrol 19:631-638

82. Ruggenenti P, Remuzzi A, Ondei P, Fasolini G, Antiga L, EneIordache B, Remuzzi G, Epstein FH (2005) Safety and efficacy of long-acting somatostatin treatment in autosomal-dominant polycystic kidney disease. Kidney Int 68:206-216

83. Serra AL, Kistler AD, Poster D, Krauer F, Senn O, Raina S, Pavik I, Rentsch K, Regeniter A, Weishaupt D, Wuthrich RP (2009) Safety and tolerability of sirolimus treatment in patients with autosomal dominant polycystic kidney disease. Nephrol Dial Transplant 24:3334-3342

84. Steinman TI (2012) Polycystic kidney disease: a 2011 update. Curr Opin Nephrol Hypertens 21:189-194

85. Swanhart LM, Cosentino CC, Diep CQ, Davidson AJ, de Caestecker CM, Hukriede NA (2011) Zebrafish kidney development: basic science to translational research. Birth Defects Res C Embryo Today 93:141-156

86. Tobin JL, Beales PL (2008) Restoration of renal function in zebrafish models of ciliopathies. Pediatr Nephrol 23:2095-2099

87. Patel V, Chowdhury R, Igarashi P (2009) Advances in the pathogenesis and treatment of polycystic kidney disease. Curr Opin Nephrol Hypertens 18:99-106

88. Hendry CE, Little MH (2012) Reprogramming the kidney: a novel approach for regeneration. Kidney Int 82:138-146

89. Itzhaki I, Maizels L, Huber I, Zwi-Dantsis L, Caspi O, Winterstern A, Feldman O, Gepstein A, Arbel G, Hammerman H, Boulos M, Gepstein L (2011) Modelling the long QT syndrome with induced pluripotent stem cells. Nature 471:225-229 